\title{
Selection of tolerant species to imazapic for potential use in phytoremediation
}

\author{
Simonny Montthiel Araújo Vasconcelo ${ }^{1} \odot$, Adriano Jakelaitis ${ }^{1} \oplus$, Leandro Spíndola Pereira ${ }^{1} \oplus$, \\ Gustavo Silva Oliveira ${ }^{1} \odot$, Gustavo Dorneles de Sousa ${ }^{1} \oplus$, Suzete Fernandes Lima ${ }^{1} \odot$

\footnotetext{
${ }^{1}$ Instituto Federal de Educação Ciência e Tecnologia Goiano, Rio Verde, GO, Brasil. E-mail: smontthiel.engeamb@gmail.com; ajakelaitis@yahoo.com.br; leandrop629@gmail.com; gustavosilvadeoliveira147@gmail.com; gustavodorneles7888@gmail.com; suzete.lima@yahoo.com.br
}

ABSTRACT: Using herbicides results in environmental impacts and it is necessary employing sustainable technologies to reduce its residues in the soil. Imazapic, used in the sugarcane cultivation, shows persistence and mobility in the environment. This study aimed to identify plant species tolerant to imazapic with the potential for phytoremediation of soils with residues of this herbicide. The tests were conducted under greenhouse conditions involving the species Urochloa decumbens, Urochloa brizantha, Urochloa ruziziensis, Mucuna pruriens, Panicum maximum, Sorghum bicolor, Crotalaria ochroleuca, Crotalaria spectabilis and Canavalia ensiformis grown in two soils: one of sandy clay loam texture and the other of sandy clay texture. In each test, five imazapic doses $(0.00,58.33,87.50$, 175.00 and $350.00 \mathrm{~g} \mathrm{ha}^{-1}$ ) were applied in pre-emergence. In all tests, the treatments were in randomized blocks with four replicates each. The soil of sandy clay loam texture with low organic carbon content decreased the tolerance of the evaluated species to imazapic due to its higher bioavailability. The species Canavalia ensiformis, Mucuna pruriens and Urochloa brizantha demonstrated lower phytotoxicity and higher dry matter production in the presence of the highest imazapic doses in the soil. The tolerance from these species can be considered as an indicator of their phytoremediation potential of soils contaminated with imazapic.

Key words: decontamination; herbicide; persistence; soil

\section{Seleção de plantas tolerantes ao imazapic para potencial uso na fitorremediação}

RESUMO: O uso de herbicidas resulta em impactos ambientais e torna-se necessário o emprego de tecnologias sustentáveis para redução de resíduos no solo. O imazapic é utilizado para a cultura da cana-de-açúcar, e apresenta persistência e mobilidade no ambiente. Objetivou-se com este estudo selecionar plantas tolerantes ao imazapic e com potencial para fitorremediação de solos com resíduos desse herbicida. Os ensaios foram conduzidos em casa de vegetação envolvendo as espécies Urochloa decumbens, Urochloa brizantha, Urochloa ruziziensis, Mucuna pruriens, Panicum maximum, Sorghum bicolor, Crotalaria ochroleuca, Crotalaria spectabilis e Canavalia ensiformis cultivadas em dois tipos de solos: de texturas franco argilo-arenosa e argilosa. Em cada ensaio foram aplicadas, em pré-emergência, cinco doses de imazapic $(0,00 ; 58,33 ; 87,50 ; 175,00$; e 350,00 $\left.\mathrm{g} \mathrm{ha}{ }^{-1}\right)$. Em todos os ensaios, os tratamentos foram delineados em blocos ao acaso com quatro repetições. 0 solo de textura franco argilo-arenosa e com menor teor de carbono orgânico diminuiu a tolerância das espécies avaliadas ao imazapic, em função da maior biodisponibilidade do herbicida. As espécies Canavalia ensiformis, Mucuna pruriens e Urochloa brizantha apresentaram menor fitointoxicação e maior produção de matéria seca na presença das maiores das doses do imazapic no solo. A tolerância dessas espécies pode ser considerada um indicador de seu potencial fitorremediador de solos contaminados com imazapic.

Palavras-chave: descontaminação; herbicida; persistência; solo 


\section{Introduction}

Rapid industrialization, urbanization and changes in the agricultural practices have all resulted in increasing contamination of the soil and aquatic ecosystems. Among the most common contaminants organic, herbicides represent the major part of the general pesticides usage in the world and can present ecological risks to non-target organisms (Tripathi et al., 2015).

Part of the imidazolinones chemical group, the imazapic has as its action mechanism the inhibition of the acetolactate synthase enzyme (ALS), which is responsible for catalyzing the biosynthesis of valine, leucine and isoleucine, three branched-chain amino acids. Inhibiting this enzyme promotes the deficiency of these amino acids, resulting in growth interruption, chlorosis and death of the plant (Zhao et al., 2017). ALS-inhibiting herbicides have been widely used for their high efficacy when in low doses, broad control spectrum, low toxicity to mammals $\left(\mathrm{DL}_{50}>5 \mathrm{~g} \mathrm{~kg}^{-1}\right)$ and selectivity (Dor et al., 2016; Duke et al., 2018; Nandula et al., 2019).

Due to its high residual activity, having a half-life of over 120 days in the soil, imazapic can cause phytotoxicity in sensitive crops sown in succession (Sousa et al., 2012; Kemmerich et al., 2015). The imazethapyr-imazapic mixture at the $200 \mathrm{~g} \mathrm{ha}^{-1}$ dose, under greenhouse conditions, caused reductions in the shoot dry weight of $78,95,98$ and $100 \%$, respectively, for maize, cucumber, radish and tomato plants at 1,100 days after application (DAA) in an Albaqualf (Planossolo Háplico Eutrófico solódico, according to Embrapa) with $16 \%$ of clay (Sousa et al., 2012).

In addition to negative impact on the yield of crops in succession or rotation, there are reports of the imazapic presence in water samples, both in the surface and the underground. Imazapic residues were in $52.6 \%$ of surface water samples and in $51.8 \%$ of the groundwater samples, in a rice cultivation area from Tanjung Karang (Malaysia), with concentrations ranging from 0.28 to $16 \mu \mathrm{g} \mathrm{mL}^{-1}$ (Mazlan et al., 2016). In a sugarcane cultivation area, located in Buenos Aires (Argentina), imazapic was detected in $60 \%$ of surface water samples, with $40 \%$ of this total in concentrations above the quantification limit (0.048 $\left.\mu \mathrm{g} \mathrm{L}^{-1}\right)$ (Gerónimo et al., 2014).

Therefore, the development of strategies for removing persistent molecules such as imazapic is of great relevance. A potential process for removing contaminants is the phytoremediation (Santos et al., 2019; Escoto et al., 2019). This technique is based on using plants and associated microorganisms to remedy soils, sediments and water contaminated by metals and organic compounds. In this process, organic pollutants can be absorbed, metabolized or degraded by enzymes and then incorporated into the plant tissue (Madalão et al., 2017).

Phytoremediation works effectively for organic contaminants present in relatively low concentrations, having its performance optimized when combined with other technologies (Montpetit \& Lachapelle, 2017). Its efficiency requires a careful selection of the plant species to be used in the process. The ideal characteristics for this selection depend on the ability to tolerate relevant concentrations of the contaminant to be remedied, as well as co-contaminants presence, biomass rapid growth and high production, development in soils poor in nutrients, existence of deep and dense roots, the time required for adequate soil cleaning and the remediation goals (Gerhardt et al., 2017).

Based on the foregoing, the objective was to identify plant species that are tolerant to the imazapic herbicide and to evaluate the use potential of these same plants in the phytoremediation programs.

\section{Materials and Methods}

The tests were conducted in Rio Verde, GO $\left(17^{\circ} 48^{\prime} 28.2^{\prime \prime}\right.$ South and 50 54'09.9" West), in an air-conditioned greenhouse (Van der Hoeven, model Double Poly Pad Fan), with temperatures ranging from 18 to $29^{\circ} \mathrm{C}$. The experimental units consisted of polyethylene pots with capacity for $6 \mathrm{dm}^{3}$, filled with two soil types (one of sandy clay loam texture and the other of sandy clay texture) with different texture and organic carbon content, collected in an area with no history of herbicide application. The substrate, previously air-dried, was subjected to the $2 \mathrm{~mm}$-mesh sieving process and then, afterwards, samples were taken in order to be physically and chemically analyzed. The soil main characteristics were the following: soil of sandy clay loam texture (SCLTS) with $63 \%$ sand, $5 \%$ silt, $32 \%$ clay, $15.4 \mathrm{~g} \mathrm{dm}^{-3}$ organic carbon (OC), base saturation ( $\mathrm{V}$ ) of $32 \%$, cation exchange capacity (CEC) of $7.1 \mathrm{cmolc}^{-\mathrm{dm}^{-3}}, \mathrm{pH}\left(\mathrm{CaCl}_{2}\right)$ of 5.3; and the soil of sandy clay texture (SCTS) with $50 \%$ sand, $10 \%$ silt, $40 \%$ clay, $26.8 \mathrm{~g} \mathrm{dm}^{-3}$ of OC, $\mathrm{V}$ of $50.7 \%$, CEC of $7.69 \mathrm{cmolc} . \mathrm{dm}^{-3}$ and $\mathrm{pH}\left(\mathrm{CaCl}_{2}\right)$ of 5.2 (Embrapa, 1997).

The selection of tolerant species was based on the method proposed by Madalão et al. (2012) in which the used species were described in the literature as tolerant to the herbicide, or then reported as phytoremediation agents of other herbicides from the same chemical group, in addition to the preference for species with agricultural and/or economic value. A test trial was set up for each vegetal species, which were the Urochloa decumbens ("capim-braquiária" or signal grass), Urochloa brizantha cv. Marandu ("braquiarão" or palisade grass), Urochloa ruziziensis ("capim-ruziziensis" or bongo grass), Mucuna pruriens cv. Mucuna cinza ("mucuna" or velvet bean), Panicum maximum cv. Mombaça ("colonião" or guinea grass), Sorghum bicolor ("sorgo" or sorghum), Crotalaria ochroleuca ("crotalaria" or rattlepod), Crotalaria spectabilis ("crotalaria" or showy rattlepod) and Canavalia ensiformis ("feijão-deporco" or jack bean). These tests were in two different stages, one from March to May 2016 for SCTS and the other from September to November 2016 for the SCLTS. Treatments consisted of five imazapic doses $(0.00 ; 58.33$; 87.50; 175.00 ; and $350.00 \mathrm{~g} \mathrm{ha}^{-1}$ ) which represented zero, one third, half, dose and twice of the recommended dose for controlling weeds in the sugarcane crop. The experimental design used in the treatments was randomized blocks, with four replicates. 
After finishing the sowing, imazapic was applied in preemergence, by using a precision sprayer pressurized with carbon dioxide $\left(\mathrm{CO}_{2}\right)$, with the application volume of $250 \mathrm{~L}$ $\mathrm{ha}^{-1}$. Thinning was performed after 10 days of the seedling emergence, leaving three plants per pot. Daily irrigation was held for maintaining the substrate moisture.

At 30 and 60 days after emergence (DAE), the phytotoxicity symptoms (\%) and the plant height $(\mathrm{cm})$ were evaluated. Phytotoxicity was determined by visual evaluation means, using a percentage scale from 0 (no injury) to $100 \%$ (complete death of the plant) (Velini et al., 1995). The height measurement analysis was with a graduated scale, having as reference the apical meristem for the dicots and the last expanded leaf for the monocots. With 60 days after emergence elapsed, the species were then removed from the experimental units, followed by the separation of shoot and root system, drying in an oven with forced air circulation at $70{ }^{\circ} \mathrm{C}$ for $72 \mathrm{~h}$ and weighing to determine the dry weight. Means referring to the plants height and the dry weights of shoot (SDW) and root (RDW), obtained through the control group of each species (zero dose), within each dose, were all transformed, thus attributing them an index equal to one.

The results for each type of soil went under the analysis of variance, at the level of $5 \%$ significance, and the regression analysis. The models choice was based on the significance of the parameters, biological response and the $\mathrm{R}^{2}$ values. Subsequently, the models defined for each soil type were subjected to the model identity analysis and also equality of parameters.

\section{Results and Discussion}

At $30 \mathrm{DAE}$, in each soil, the herbicide phytotoxicity for $U$. decumbens was distinctive, while in the SCLTS this effect was more evident with increasing doses, representing increases of 0.20 and $0.15 \%$ for each $\mathrm{g} \mathrm{ha} \mathrm{h}^{-1}$ of applied herbicide to the plants grown in the SCLTS and SCTS, respectively (Table 1). From 60 DAE onwards, in SCTS, there was no significant herbicide phytotoxicity; however, in SCLTS, with the increasing dose, the symptom increased by $0.24 \%$ for each $g \mathrm{ha}^{-1}$ of applied herbicide, reaching $81 \%$ of phytotoxicity in the $U$. decumbens plants at the $350 \mathrm{~g} \mathrm{ha}^{-1}$ dose.

At the $30 \mathrm{DAE}$, despite the soil type that $U$. decumbens was grown in, there was a height reduction of $0.1 \%$ with the increasing imazapic doses. At $60 \mathrm{DAE}$, no effect of the herbicide on the height of plants grown in SCTS was observed, while in SCLTS, some linear decreases occurred, reaching reductions of 30 and $65 \%$ of this variable at the doses of 175 and $350 \mathrm{~g} \mathrm{ha}^{-1}$, respectively, in comparison to the control (Table 1 ).

At the $60 \mathrm{DAE}$, with the increasing doses, there were linear reductions in SDW and RDW in all plants grown in both soils. For SDW, the reductions represented $0.25 \%$ and $0.14 \%$ for each $g$ ha $^{-1}$ of applied herbicide in SCLTS and SCTS, respectively. The RDW of the plants grown in SCTS demonstrated a linear decrease of $0.11 \%$ for each $g \mathrm{ga}^{-1}$ of the applied herbicide, while the effects on the RDW from plants grown in SCLTS were more representative and their response was fit to the logistic model, with reduction of $50 \%$ RDW at the $53 \mathrm{~g} \mathrm{ha}^{-1}$ dose and absence in their production in doses close to $350 \mathrm{~g} \mathrm{ha}^{-1}$ (Table 1).

Urochloa brizantha plants grown in both soil types had low phytotoxicity levels when exposed to the imazapic doses in the evaluations performed at 30 and 60 DAE. For plants grown at SCTS, no dose effects were verified at $30 \mathrm{DAE}$, with a mean phytotoxicity of $1.25 \%$; while in SCLTS, linear increases of $0.06 \%$ were observed for each $g$ ha $^{-1}$ of applied herbicide, reaching $26 \%$ when exposed to the highest herbicide dose (Table 1). At $60 \mathrm{DAE}$, with the increasing doses, phytotoxicity increased by $0.05 \%$ for each $\mathrm{g} \mathrm{ha}^{-1}$ of applied herbicide, regardless of the soil type that $U$. brizantha was grown in.

Plant height was not influenced by the imazapic doses when $U$. brizantha was grown at SCTS. However, in SCLTS at 30 DAE, significant effects were observed and the response was then fit to the logistic model with a reduction in this variable of 16 and $43 \%$, respectively, at the doses of 58 and $350 \mathrm{~g} \mathrm{ha}^{-1}$. At $60 \mathrm{DAE}$, there were linear decreases of $0.12 \%$ in the plant height for each $\mathrm{g} \mathrm{ha}^{-1}$ of applied herbicide, demonstrating a $32 \%$ reduction in the $350 \mathrm{~g} \mathrm{ha}^{-1}$ dose in relation to the zero dose (Table 1).

Similar to what happened with the height of $U$. brizantha plants grown at SCTS, no effects were observed between doses for both SDW and RDW. However, with the increasing dose applied in the SCLTS, there were linear reductions of 0.19 and $0.18 \%$ in the accumulation of SDW and RDW from $U$. brizantha, respectively, for each $g \mathrm{ha}^{-1}$ of applied herbicide (Table 1).

At $30 \mathrm{DAE}$, Urochloa ruziziensis plants demonstrated a greater phytotoxicity when grown in SCLTS than when in SCTS. For each increment in the applied dose ( $\mathrm{g} \mathrm{ha} \mathrm{h}^{-1}$ of applied herbicide), phytotoxicity increases of $0.24 \%$ and $0.045 \%$ were observed in the plants grown in SCLTS and SCTS, respectively. At $60 \mathrm{DAE}$, in the SCLTS, the phytotoxicity of $U$. ruziziensis was reduced by $0.11 \%$ for each $\mathrm{g} \mathrm{ha} \mathrm{h}^{-1}$ of applied herbicide and, while in SCTS there was no effect between doses on cultivated plants and the mean phytotoxicity was $1.56 \%$ (Table 1 ).

Linear reductions in the height of $U$. ruziziensis plants were found during evaluations performed at 30 and $60 \mathrm{DAE}$, in both soils types. At $30 \mathrm{DAE}$, for each $\mathrm{g} \mathrm{ha}^{-1}$ of applied herbicide, there were reductions of 0.18 and $0.10 \%$ in plants grown in SCLTS and SCTS, respectively, also characterizing reductions of 76 and $13 \%$ in plants subjected to the highest herbicide dose (350 $\mathrm{g} \mathrm{ha}^{-1}$ ), when compared to the control group. In a similar fashion, the reduction in plant size at 60 DAE was of 0.17 and $0.07 \%$ for each $g$ ha $^{-1}$ of applied herbicide in SCLTS and SCTS, respectively. There were linear reductions for the SDW production of 0.24 and $0.11 \%$ and for the RDW they were of 0.23 and $0.19 \%$, regarding $U$. ruziziensis plants grown in SCLTS and SCTS, respectively (Table 1 ).

Table 2 displays the results obtained from the species Mucuna pruriens, Panicum maximum and Sorghum bicolor. Low phytotoxicity levels were observed for $M$. pruriens, as a function of the increasing imazapic doses. At 30 and $60 \mathrm{DAE}$, 
Table 1. Phytotoxicity at 30 (FT_30) and at 60 (FT_60) days after emergence (DAE) and height indexes at 30 (IA_30) and at 60 (IA_60) DAE of the dry weights of shoot (SDW) and root (RDW) from U. decumbens, U. brizantha and U. ruziziensis, in function of the imazapic doses applied in two soils.

\begin{tabular}{|c|c|c|c|c|c|c|c|}
\hline \multirow{2}{*}{ Variables } & \multicolumn{5}{|c|}{ Doses $\left(\mathrm{g} \mathrm{ha}^{-1}\right)$} & \multirow{2}{*}{ Equation } & \multirow{2}{*}{$\mathbf{R}^{2}$} \\
\hline & 0 & 58.33 & 87.5 & 175 & 350 & & \\
\hline & \multicolumn{7}{|c|}{ Urochloa decumbens in a soil of clay-sandy loam texture } \\
\hline FT_30 & 0.0 & 0.00 & 10.00 & 62.50 & 60.00 & $\widehat{Y}=-0.6936+0.2027 x$ & 0.75 \\
\hline FT_60 & 0.0 & 8.75 & 2.50 & 53.75 & 77.50 & $\hat{Y}=-4.3117+0.2446 x$ & 0.90 \\
\hline IA_30 & 1.0 & 0.95 & 0.79 & 0.53 & 0.49 & $\hat{Y}=0.9608-0.0016 x$ & 0.82 \\
\hline |A_60 & 1.0 & 0.98 & 1.04 & 0.44 & 0.43 & $\hat{Y}=1.0419-0.0020 x$ & 0.73 \\
\hline SDW & 1.0 & 0.86 & 0.78 & 0.21 & 0.19 & $\hat{Y}=0.9442-0.0025 x$ & 0.81 \\
\hline \multirow[t]{2}{*}{ RDW } & 1.0 & 0.63 & 0.59 & 0.12 & 0.13 & $\widehat{\mathrm{Y}}=1.4217 /\left(1+\exp ^{(-(x-52.9439 /-62.9555)}\right)$ & 0.96 \\
\hline & \multicolumn{7}{|c|}{ Urochloa decumbens in a soil of sandy clay texture } \\
\hline FT_30 & 0.00 & 0.00 & 0.00 & 18.25 & 46.25 & $\widehat{Y}=-6.5021+0.1446 x$ & 0.94 \\
\hline FT_60 & 0.00 & 1.58 & 1.58 & 1.58 & 1.58 & $\hat{Y}=\bar{Y}=1.58$ & - \\
\hline IA_30 & 1.00 & 0.95 & 0.79 & 0.53 & 0.49 & $\hat{Y}=0.9608-0.0016 x$ & 0.82 \\
\hline IA_60 & 1.00 & 1.08 & 1.08 & 1.08 & 1.08 & $\widehat{Y}=\bar{Y}=1.08$ & - \\
\hline SDW & 1.00 & 0.84 & 0.82 & 0.67 & 0.49 & $\hat{Y}=0.9484-0.0014 x$ & 0.96 \\
\hline \multirow[t]{2}{*}{ RDW } & 1.00 & 0.83 & 0.97 & 0.56 & 0.63 & $\hat{Y}=0.9506-0.0011 x$ & 0.61 \\
\hline & \multicolumn{7}{|c|}{ Urochloa brizantha in a soil of clay-sandy loam texture } \\
\hline FT_30 & 0.00 & 10.42 & 7.92 & 15.83 & 25.42 & $\hat{Y}=2.9225+0.0670 x$ & 0.93 \\
\hline FT_60 & 0.00 & 3.54 & 0.00 & 7.08 & 18.23 & $\hat{Y}=1.3825+0.0533 x$ & 0.92 \\
\hline IA_30 & 1.00 & 0.80 & 0.82 & 0.60 & 0.58 & $\widehat{Y}=0.5646+0.6586 /\left(1+\exp ^{(-(37.8958) /-60.6719)}\right)$ & 0.96 \\
\hline IA_60 & 1.00 & 1.03 & 1.14 & 0.83 & 0.67 & $\hat{Y}=1.0908-0.0012 x$ & 0.74 \\
\hline SDW & 1.00 & 0.68 & 0.69 & 0.47 & 0.27 & $\hat{Y}=0.8758-0.0019 x$ & 0.89 \\
\hline \multirow[t]{2}{*}{ RDW } & 1.00 & 0.50 & 0.60 & 0.36 & 0.22 & $\widehat{Y}=0.7841-0.0018 x$ & 0.72 \\
\hline & \multicolumn{7}{|c|}{ Urochloa brizantha in a soil of sandy clay texture } \\
\hline FT_30 & 0.00 & 1.25 & 1.25 & 1.25 & 1.25 & $\hat{Y}=\hat{Y}=1.25$ & - \\
\hline FT_60 & 0.00 & 3.54 & 0.00 & 7.08 & 18.23 & $\hat{Y}=1.3825+0.0533 x$ & 0.92 \\
\hline IA_30 & 1.00 & 1.00 & 1.00 & 1.00 & 1.00 & $\hat{Y}=\hat{Y}=1.00$ & - \\
\hline |A_60 & 1.00 & 1.00 & 1.00 & 0.82 & 0.45 & $\hat{Y}=1.0808-0.0017 x$ & 0.94 \\
\hline SDW & 1.00 & 1.00 & 1.00 & 1.00 & 1.00 & $\hat{Y}=\bar{Y}=1.00$ & - \\
\hline \multirow[t]{2}{*}{ RDW } & 1.00 & 0.90 & 0.90 & 0.90 & 0.90 & $\hat{\mathrm{Y}}=\overline{\mathrm{Y}}=0.90$ & - \\
\hline & \multicolumn{7}{|c|}{ Urochloa ruziziensis in a soil of clay-sandy loam texture } \\
\hline FT_30 & 0.00 & 10.56 & 5.00 & 23.89 & 82.22 & $Y=-7.6577+0.2384 x$ & 0.94 \\
\hline FT_60 & 0.00 & 5.00 & 1.67 & 13.33 & 35.00 & $\widehat{Y}=-2.8210+0.1090 x$ & 0.95 \\
\hline IA_30 & 1.00 & 0.58 & 0.64 & 0.49 & 0.25 & $\hat{Y}=0.8379-0.0018 x$ & 0.83 \\
\hline |A_60 & 1.00 & 1.00 & 1.00 & 1.00 & 1.00 & $\hat{Y}=\bar{Y}=1.00$ & - \\
\hline SDW & 1.00 & 0.85 & 0.85 & 0.51 & 0.19 & $\hat{Y}=1.0006-0.0024 x$ & 0.98 \\
\hline \multirow[t]{2}{*}{ RDW } & 1.00 & 0.52 & 0.60 & 0.29 & 0.07 & $\hat{Y}=0.7991-0.0023 x$ & 0.83 \\
\hline & \multicolumn{7}{|c|}{ Urochloa ruziziensis in a soil of sandy clay texture } \\
\hline FT_30 & 0.00 & 0.00 & 0.00 & 1.67 & 15.00 & $\hat{Y}=-2.6452+0.0446 x$ & 0.86 \\
\hline FT_60 & 0.00 & 1.56 & 1.56 & 1.56 & 1.56 & $\widehat{Y}=\bar{Y}=1.56$ & - \\
\hline IA_30 & 1.00 & 0.89 & 0.89 & 0.80 & 0.64 & $\widehat{Y}=0.9750-0.0010 x$ & 0.98 \\
\hline IA_60 & 1.00 & 0.91 & 1.09 & 0.89 & 0.78 & $\hat{Y}=1.0248-0.0007 x$ & 0.61 \\
\hline SDW & 1.00 & 0.90 & 1.02 & 1.04 & 0.60 & $\hat{Y}=1.0538-0.0011 x$ & 0.62 \\
\hline RDW & 1.00 & 0.94 & 0.68 & 0.45 & 0.37 & $\widehat{Y}=0.9383-0.0019 x$ & 0.82 \\
\hline
\end{tabular}

mean linear increments of $0.05 \%$ were found for each $\mathrm{g} \mathrm{ha}^{-1}$ of applied herbicide and the values at the maximum applied dose $\left(350 \mathrm{~g} \mathrm{ha}^{-1}\right)$ were less than $20 \%$, regardless of the soil type that the plants were grown in. Similarly, there was variation in the plant height and a linear decrease of $0.15 \%$ in height at 30 DAE occurred in both soil types and of $0.07 \%$ at 60 DAE in SCLTS for each $g$ ha $^{-1}$ of applied herbicide. In SCTS, no significant effects in relation to the doses were found and the height index was similar to the observed for the control group (Table 2).

The SDW fit to the linear regression model for SCLTS, with an estimated decrease of $0.07 \%$ in comparison to the control and maximum inhibition of $22 \%$ in the highest tested dose. In this same soil, the logistic model was what best explained the RDW in M. pruriens plants, which had inhibition values close to $30 \%$ until the estimated dose of $88 \mathrm{~g} \mathrm{ha}^{-1}$, remaining constant until the $350 \mathrm{~g} \mathrm{ha}^{-1}$ dose. No dose effects were observed on the SDW and RDW of plants grown in SCTS (Table 2).

Regardless of the soil type that the Panicum maximum plants were grown, linear increases in the phytotoxicity values were observed when these plants were exposed to imazapic doses (Table 2). For each $\mathrm{g} \mathrm{ha}^{-1}$ of applied herbicide, the symptoms increased by 0.29 and $0.26 \%$ in the evaluations performed at 30 and $60 \mathrm{DAE}$, respectively. Compared to the 
Table 2. Phytotoxicity at 30 (FT_30) and 60 (FT_60) days after emergence (DAE) and height indexes at 30 (IA_30) and 60 (IA_60) DAE of the dry weights of shoot (SDW) and root (RDW) from M. pruriens, P.maximum and Sorghum bicolor as a function of imazapic doses applied in two soils.

\begin{tabular}{|c|c|c|c|c|c|c|c|}
\hline \multirow{2}{*}{ Variables } & \multicolumn{5}{|c|}{ Doses $\left(\mathrm{g} \mathrm{ha}^{-1}\right)$} & \multirow{2}{*}{ Equation } & \multirow{2}{*}{$\mathbf{R}^{2}$} \\
\hline & 0 & 58.33 & 87.5 & 175 & 350 & & \\
\hline & \multicolumn{7}{|c|}{ Mucuna pruriens in a soil of clay-sandy loam texture } \\
\hline FT_30 & 0.00 & 0.00 & 0.42 & 3.75 & 16.15 & $\hat{Y}=-2.4820+0.0488 x$ & 0.89 \\
\hline FT_60 & 0.00 & 1.25 & 0.63 & 2.50 & 18.33 & $\hat{Y}=-2.5757+0.0530 x$ & 0.86 \\
\hline IA_30 & 1.00 & 1.02 & 0.92 & 0.73 & 0.54 & $\hat{Y}=1.0391-0.0015 x$ & 0.95 \\
\hline IA_60 & 1.00 & 1.16 & 1.05 & 0.75 & 0.60 & $\hat{P}=1.1125-0.0015 x$ & 0.78 \\
\hline SDW & 1.00 & 1.05 & 0.98 & 0.87 & 0.79 & $\widehat{Y}=1.0353-0.0007 x$ & 0.86 \\
\hline \multirow[t]{2}{*}{ RDW } & 1.00 & 0.76 & 0.70 & 0.65 & 0.63 & $\widehat{Y}=0.6316+0.995 /(1+\exp (-(x+22.5023 /-42.3613))$ & 0.99 \\
\hline & \multicolumn{7}{|c|}{ Mucuna pruriens in a soil of sandy clay texture } \\
\hline FT_30 & 0.00 & 0.00 & 0.42 & 3.75 & 16.15 & $\hat{Y}=-2.4820+0.0488 x$ & 0.89 \\
\hline FT_60 & 0.00 & 1.25 & 0.63 & 2.50 & 18.33 & $\hat{\mathrm{Y}}=-2.5757+0.0530 \mathrm{x}$ & 0.86 \\
\hline IA_30 & 1.00 & 1.02 & 0.92 & 0.73 & 0.54 & $\hat{Y}=1.0391-0.0015 x$ & 0.95 \\
\hline IA_60 & 1.00 & 0.89 & 0.89 & 0.89 & 0.89 & $\hat{\mathrm{Y}}=\overline{\mathrm{Y}}=0.89$ & - \\
\hline SDW & 1.00 & 1.05 & 1.05 & 1.05 & 1.05 & $\hat{\mathrm{Y}}=\overline{\mathrm{Y}}=1.05$ & - \\
\hline \multirow[t]{2}{*}{ RDW } & 1.00 & 1.05 & 1.05 & 1.05 & 1.05 & $\hat{Y}=\bar{Y}=1.05$ & - \\
\hline & \multicolumn{7}{|c|}{ Panicum maximum in a soil of clay-sandy loam texture } \\
\hline FT_30 & 0.00 & 17.71 & 6.38 & 65.04 & 95.00 & $\widehat{Y}=-2.0962+0.2901 x$ & 0.91 \\
\hline FT_60 & 0.00 & 10.63 & 19.03 & 47.43 & 88.21 & $\hat{\mathrm{Y}}=-1.8146+0.2599 \mathrm{x}$ & 0.99 \\
\hline IA_30 & 1.00 & 0.81 & 0.69 & 0.33 & 0.08 & $\hat{Y}=0.9397-0.0027 x$ & 0.94 \\
\hline IA_60 & 1.00 & 1.01 & 1.15 & 0.44 & 0.22 & $\widehat{Y}=1.1241-0.0027 x$ & 0.80 \\
\hline SDWW & 1.00 & 0.63 & 0.48 & 0.22 & 0.04 & $\hat{Y}=0.8125-0.0025 x$ & 0.85 \\
\hline \multirow[t]{2}{*}{ RDW } & 1.00 & 0.75 & 0.55 & 0.33 & 0.03 & $\hat{Y}=0.8867-0.0027 x$ & 0.93 \\
\hline & \multicolumn{7}{|c|}{ Panicum maximum in a soil of sandy clay texture } \\
\hline FT_30 & 0.00 & 17.71 & 6.38 & 65.04 & 95.00 & $\hat{Y}=-2.0962+0.2901 x$ & 0.91 \\
\hline FT_60 & 0.00 & 10.63 & 19.03 & 47.43 & 88.21 & $\widehat{Y}=-1.8146+0.2599 x$ & 0.99 \\
\hline IA_30 & 1.00 & 0.81 & 0.69 & 0.33 & 0.08 & $\hat{Y}=0.9397-0.0027 x$ & 0.94 \\
\hline IA_60 & 1.00 & 1.01 & 1.15 & 0.44 & 0.22 & $\hat{Y}=1.1241-0.0027 x$ & 0.80 \\
\hline SDW & 1.00 & 0.91 & 1.18 & 0.63 & 0.08 & $\widehat{Y}=1.1475-0.0029 x$ & 0.85 \\
\hline \multirow[t]{2}{*}{ RDW } & 1.00 & 0.75 & 0.55 & 0.33 & 0.03 & $\hat{Y}=0.8867-0.0027 x$ & 0.93 \\
\hline & \multicolumn{7}{|c|}{ Sorghum bicolor in a soil of clay-sandy loam texture } \\
\hline FT_30 & 0.00 & 23.33 & 30.42 & 71.08 & 82.17 & $\widehat{\mathrm{Y}}=82.0387 /\left(1+\exp ^{(-(x-103.6231) / 37.7296)}\right)$ & 0.99 \\
\hline FT_60 & 0.00 & 33.89 & 42.50 & 84.17 & 100.00 & $\hat{Y}=96.2762 /(1+\exp (-(x-96.2762) / 40.2979))$ & 0.98 \\
\hline IA_30 & 1.00 & 0.89 & 0.81 & 0.44 & 0.21 & $\widehat{Y}=0.9875-0.0024 x$ & 0.95 \\
\hline IA_60 & 1.00 & 0.84 & 0.64 & 0.16 & 0.00 & $\widehat{\mathrm{Y}}=1.0729 /\left(1+\exp ^{(-(x-105.1073) /-39.0718)}\right)$ & 0.99 \\
\hline SDW & 1.00 & 0.49 & 0.24 & 0.09 & 0.00 & $\hat{\mathrm{Y}}=1.8490 /\left(1+\exp ^{(-(-x-7.8166) /-46.3463)}\right)^{\prime}$ & 0.99 \\
\hline \multirow[t]{2}{*}{ RDW } & 1.00 & 0.34 & 0.13 & 0.08 & 0.00 & $\hat{Y}=5.2108 /\left(1+\exp ^{(-(x+64.7631) /-45.0858)}\right)$ & 0.99 \\
\hline & \multicolumn{7}{|c|}{ Sorghum bicolor in a soil of sandy clay texture } \\
\hline FT_30 & 0.00 & 0.00 & 0.00 & 52.50 & 86.25 & $\widehat{Y}=-9.7962+0.2698 x$ & 0.92 \\
\hline FT_60 & 0.00 & 2.75 & 15.83 & 48.75 & 89.17 & $\hat{Y}=-5.5942+0.2735 x$ & 0.98 \\
\hline IA_30 & 1.00 & 0.89 & 0.81 & 0.44 & 0.21 & $\hat{Y}=0.9875-0.0024 x$ & 0.95 \\
\hline IA_60 & 1.00 & 1.08 & 0.88 & 0.38 & 0.06 & $\widehat{\mathrm{Y}}=1.0528 /\left(1+\exp ^{(-(x-155.0286) /-34.1682)}\right)$ & 0.98 \\
\hline SDW & 1.00 & 0.77 & 0.77 & 0.60 & 0.11 & $\hat{Y}=0.9748-0.0024 x$ & 0.99 \\
\hline RDW & 1.00 & 0.63 & 0.43 & 0.34 & 0.04 & $\hat{Y}=0.8142-0.0024 x$ & 0.86 \\
\hline
\end{tabular}

control, the increases in phytotoxicity represented 99 and $89 \%$ in the $350 \mathrm{~g} \mathrm{ha}^{-1}$ dose, during evaluations performed at 30 and $60 \mathrm{DAE}$, respectively. These symptoms contributed to the linear reduction of plant size by an average of $0.27 \%$, at 30 and $60 \mathrm{DAE}$ for each $\mathrm{g} \mathrm{ha}^{-1}$ of applied herbicide (Table 2).

Regarding the SDW from $P$. maximum, linear reductions of 0.25 and $0.29 \%$ were observed, respectively, in SCLTS and SCTS with the increasing imazapic doses. However, for each $\mathrm{g} \mathrm{ha}^{-1}$ of applied herbicide, in both soil types, the RDW had a linear decrease of $0.27 \%$ (Table 2). The $S$. bicolor proved to be susceptible to the increased doses of the imazapic herbicide when grown in both soil types (Table 2 ). The phytotoxicity symptoms in SCLTS were more intense in relation to SCTS and are explained by logistic models, in which the doses of 120 and $97 \mathrm{~g} \mathrm{ha}^{-1}$ represented $50 \%$ of the values in the response variable for the evaluations at 30 and $60 \mathrm{DAE}$, respectively, with phytotoxicity symptoms above $70 \%$ in doses above $175 \mathrm{~g}$ $\mathrm{ha}^{-1}$. In SCTS, there was a rising linear effect with the increasing imazapic doses, in both evaluation periods, with an increase of $0.27 \%$ for each $g$ ha $^{-1}$ of applied herbicide (Table 2 ).

At $30 \mathrm{DAE}$, the size of the sorghum plants demonstrated a linear reduction when subjected to imazapic doses, with unit losses of $0.2 \%$, not differing as to the cultivated soil type. At 60 DAE, plants grown in SCLTS were more susceptible, with 50\% 
of height inhibition at the $110 \mathrm{~g} \mathrm{ha}^{-1}$ dose, while in SCTS this same reduction was at the $159 \mathrm{~g} \mathrm{ha}^{-1}$ dose (Table 2).

The logistic model also satisfactorily described the relation between the imazapic doses and the variables SDW and RDW of plants grown in SCLTS. In this substrate, doses 53 and $36 \mathrm{~g} \mathrm{ha}^{-1}$ promoted a $50 \%$ reduction in the production of SDW and RDW, respectively, with reductions in these variables close to $100 \%$ in the doses above $175 \mathrm{~g}$ $\mathrm{ha}^{-1}$ of imazapic, indicating the complete death of the plant. In SCTS, linear reductions were observed with the increasing doses, having a unit reduction ( $\mathrm{g} \mathrm{ha}^{-1}$ of applied herbicide) of $0.24 \%$ in SDW and RDW (Table 2 ).
Phytotoxicity of the $C$. ochroleuca grown in SCLTS and evaluated at 30 and $60 \mathrm{DAE}$, fit to the increasing exponential models, demonstrating a greater sensitivity to imazapic, when compared to plants grown at SCTS, in which the increasing linear models (Table 3 ) explained the results. Phytotoxicity values above $80 \%$ were verified in doses above $70 \mathrm{~g} \mathrm{ha}^{-1}$ in plants grown at SCLTS, regardless of the evaluation period at hand. Higher levels of tolerance were observed in plant cultivation at SCTS, in which, no matter the evaluated period, the phytotoxicity was of $0.16 \%$ for each $\mathrm{g} \mathrm{ha}{ }^{-1}$ of applied herbicide. The increased imazapic dose caused phytotoxicity of 62 and $50 \%$ in the $350 \mathrm{~g} \mathrm{ha}^{-1}$ dose at

Table 3. Phytotoxicity at 30 (FT_30) and 60 (FT_60) days after emergence (DAE) and height indexes at 30 (IA_30) and 60 (IA_60) DAE of dry weights of shoot (SDW) and root (RDW) from Crotalaria ochroleuca, Crotalaria spectabilis and Canavalia ensiformis as a function of imazapic doses applied in two soils.

\begin{tabular}{|c|c|c|c|c|c|c|c|}
\hline \multirow{2}{*}{ Variables } & \multicolumn{5}{|c|}{ Doses (g ha-1) } & \multirow{2}{*}{ Equation } & \multirow{2}{*}{$\mathbf{R}^{\mathbf{2}}$} \\
\hline & 0 & 58.33 & 87.5 & 175 & 350 & & \\
\hline & \multicolumn{7}{|c|}{ Crotalaria ochroleuca in a soil of clay-sandy loam texture } \\
\hline FT_30 & 0.00 & 84.17 & 72.75 & 93.33 & 92.92 & $\widehat{Y}=90.3025\left(1-\exp ^{-0.0331 x}\right)$ & 0.96 \\
\hline FT_60 & 0.00 & 80.00 & 92.92 & 95.00 & 92.33 & $\widehat{Y}=94.4996\left(1-\exp ^{-0.0343 x}\right)$ & 0.99 \\
\hline IA_30 & 1.00 & 0.21 & 0.46 & 0.14 & 0.19 & $\widehat{Y}=0.9570 \exp ^{-0.0135 x}$ & 0.77 \\
\hline IA_60 & 1.00 & 0.17 & 0.10 & 0.10 & 0.15 & $\widehat{Y}=0.9980 \exp ^{-0.0282 x}$ & 0.95 \\
\hline SDW & 1.00 & 0.14 & 0.05 & 0.05 & 0.05 & $\widehat{Y}=0.9999 \exp ^{-0.0035 x}$ & 0.99 \\
\hline \multirow[t]{2}{*}{ RDW } & 1.00 & 0.12 & 0.04 & 0.02 & 0.01 & $\hat{Y}=1.0000 \exp ^{-0.0037 x}$ & 0.99 \\
\hline & \multicolumn{7}{|c|}{ Crotalaria ochroleuca in a soil of sandy clay texture } \\
\hline FT_30 & 0.00 & 15.00 & 10.00 & 50.00 & 55.63 & $\hat{Y}=3.6198+0.1677 x$ & 0.83 \\
\hline FT_60 & 0.00 & 0.00 & 0.00 & 19.58 & 52.50 & $\widehat{Y}=-7.5237+0.1635 x$ & 0.99 \\
\hline IA_30 & 1.00 & 0.88 & 0.79 & 0.54 & 0.29 & $\widehat{Y}=0.9757-0.0021 x$ & 0.97 \\
\hline IA_60 & 1.00 & 1.01 & 0.95 & 0.47 & 0.30 & $\hat{Y}=1.0568-0.0023 x$ & 0.88 \\
\hline SDW & 1.00 & 0.83 & 0.99 & 0.48 & 0.26 & $\widehat{Y}=1.0155-0.0023 x$ & 0.88 \\
\hline \multirow[t]{2}{*}{ RDW } & 1.00 & 0.73 & 1.00 & 0.45 & 0.45 & $\widehat{Y}=0.9455-0.0016 x$ & 0.65 \\
\hline & \multicolumn{7}{|c|}{ Crotalaria spectabilis in a soil of clay-sandy loam texture } \\
\hline FT_30 & 0.00 & 2.33 & 5.00 & 17.08 & 48.42 & $\widehat{Y}=-4.8531+0.1447 x$ & 0.96 \\
\hline FT_60 & 0.00 & 9.17 & 6.25 & 10.83 & 43.33 & $\hat{Y}=-2.0144+0.1187 x$ & 0.91 \\
\hline IA_30 & 1.00 & 0.88 & 0.90 & 0.80 & 0.61 & $\widehat{Y}=0.9675-0.0010 x$ & 0.97 \\
\hline IA_60 & 1.00 & 1.01 & 1.12 & 0.88 & 0.48 & $\widehat{Y}=1.0741 /\left(1+\exp ^{(-(x-330.1738) /-85.1925)}\right)$ & 0.93 \\
\hline SDW & 1.00 & 0.91 & 0.98 & 0.67 & 0.31 & $\hat{Y}=1.0537-0.0020 x$ & 0.95 \\
\hline \multirow[t]{2}{*}{ RDW } & 1.00 & 0.70 & 0.89 & 0.52 & 0.21 & $\widehat{Y}=0.9593-0.0022 x$ & 0.91 \\
\hline & \multicolumn{7}{|c|}{ Crotalaria spectabilis in a soil of sandy clay texture } \\
\hline FT_30 & 0.00 & 0.00 & 0.00 & 7.50 & 23.33 & $\hat{\mathrm{Y}}=-3.4957+0.0720 \mathrm{x}$ & 0.94 \\
\hline FT_60 & 0.00 & 0.00 & 0.00 & 2.22 & 22.44 & $\widehat{Y}=-3.9928+0.0660 x$ & 0.85 \\
\hline IA_30 & 1.00 & 1.02 & 1.02 & 1.02 & 1.02 & $\hat{\mathrm{Y}}=\overline{\mathrm{Y}}=1.02$ & - \\
\hline IA_60 & 1.00 & 1.10 & 1.10 & 1.10 & 1.10 & $\widehat{Y}=\bar{Y}=1.10$ & - \\
\hline SDW & 1.00 & 0.96 & 0.96 & 0.96 & 0.96 & $\widehat{Y}=\bar{Y}=0.96$ & - \\
\hline \multirow[t]{2}{*}{ RDW } & 1.00 & 0.87 & 0.87 & 0.87 & 0.87 & $\hat{Y}=\bar{Y}=0.87$ & - \\
\hline & \multicolumn{7}{|c|}{ Canavalia ensiformis in a soil of clay-sandy loam texture } \\
\hline FT_30 & 0.00 & 0.00 & 0.00 & 0.00 & 10.00 & No fitting & - \\
\hline FT_60 & 0.00 & 0.75 & 0.75 & 0.75 & 0.75 & $\widehat{Y}=\bar{Y}=0.75$ & - \\
\hline IA_30 & 1.00 & 0.91 & 0.98 & 0.84 & 0.76 & $\widehat{Y}=0.9920-0.0007 x$ & 0.87 \\
\hline IA_60 & 1.00 & 0.97 & 0.99 & 0.89 & 0.77 & $\hat{Y}=1.0185-0.0007 x$ & 0.95 \\
\hline SDW & 1.00 & 0.90 & 0.85 & 0.86 & 0.68 & $\widehat{Y}=0.9682-0.0008 x$ & 0.92 \\
\hline \multirow[t]{2}{*}{ RDW } & 1.00 & 0.99 & 1.06 & 0.88 & 0.58 & $\widehat{Y}=1.0778-0.0013 x$ & 0.85 \\
\hline & \multicolumn{7}{|c|}{ Canavalia ensiformis in a soil of sandy clay texture } \\
\hline FT_30 & 0.00 & 1.00 & 1.00 & 1.00 & 1.00 & $\hat{Y}=\bar{Y}=1.00$ & - \\
\hline FT_60 & 0.00 & 0.20 & 0.20 & 0.20 & 0.20 & $\hat{Y}=\bar{Y}=0.20$ & - \\
\hline IA_30 & 1.00 & 0.91 & 0.98 & 0.84 & 0.76 & $\widehat{Y}=0.9920-0.0007 x$ & 0.87 \\
\hline IA_60 & 1.00 & 0.97 & 0.99 & 0.89 & 0.77 & $\hat{Y}=1.0185-0.0007 x$ & 0.95 \\
\hline SDW & 1.00 & 0.90 & 0.85 & 0.86 & 0.68 & $\widehat{Y}=0.9682-0.0008 x$ & 0.92 \\
\hline RDW & 1.00 & 0.89 & 0.89 & 0.89 & 0.89 & $\widehat{Y}=\bar{Y}=0.89$ & - \\
\hline
\end{tabular}


30 and $60 \mathrm{DAE}$, respectively, when compared to the control group (Table 3 ).

The behavior referring to the symptoms observed for the phytotoxicity variable corroborates with what was verified for the height of $C$. ochroleuca plants evaluated at 30 and $60 \mathrm{DAE}$, as well as for SDW and RDW, which values were explained by decreasing exponential models in both SCLTS and SCTS (Table 3). Reductions greater than $80 \%$ for the variables height index, SDW and RDW were observed at doses below $175 \mathrm{~g} \mathrm{ha}^{-1}$ in $C$. ochroleuca plants grown at SCLTS. The effects for these same variables were attenuated for SCTS, and the reductions for each $\mathrm{g} \mathrm{ha}{ }^{-1}$ of the applied imazapic were of 0.23 and $0.21 \%$ for plant height at 30 and $60 \mathrm{DAE}$, respectively, and of 0.23 and $0.16 \%$ for SDW and RDW. Compared to the control, which did not receive the herbicide application, the reductions were of 75 and $65 \%$ for height, 78 and $62 \%$ for SDW and RDW when the plants received the highest herbicide dose $\left(350 \mathrm{~g} \mathrm{ha}^{-1}\right.$ ) (Table 3 ).

C. spectabilis proved to be more tolerant to imazapic than the $C$. ochroleuca. The phytotoxicity symptoms of $C$. spectabilis were fit to the increasing linear models regarding the evaluations performed at 30 and $60 \mathrm{DAE}$, in both soil types (Table 3). At $30 \mathrm{DAE}$, for each $\mathrm{g} \mathrm{ha}^{-1}$ of applied imazapic, the plant phytotoxicity increased by 0.15 and $0.07 \%$ in SCLTS and SCTS, respectively, and at 60 DAE it increased by 0.11 and $0.06 \%$ in SCLTS and SCTS. The mean phytotoxicity was $40 \%$ in SCLTS and $20 \%$ in SCTS, in both evaluated periods, at the highest herbicide dose applied ( $\left.350 \mathrm{~g} \mathrm{ha}^{-1}\right)$, compared to the control group (Table 3).

In the SCTS, for the phytotoxicity levels below $20 \%$, verified at the highest herbicide dose, there were no significant effects for other evaluated variables (height, SDW and RDW) in C. spectabilis plants. On the other hand, for the phytoxication levels above $20 \%$ found in SCLTS, phytoxication contributed to the reductions of height, SDW and RDW in C. spectabilis plants with the increasing imazapic doses. For the height index variable, the increased dose promoted a linear decrease of $0.10 \%$ in the plants cultivation for each $\mathrm{g} \mathrm{ha}{ }^{-1}$ of applied herbicide in SCLTS at 30 DAE (Table 3). At 60 DAE, for this same characteristic, the logistic model fitted best, and the 339 $\mathrm{g} \mathrm{ha}^{-1}$ dose reduced the plants size by $50 \%$. For each $\mathrm{g} \mathrm{ha}^{-1}$ of imazapic applied in the SCLTS, the linear reductions of the SDW were $0.20 \%$ while of the RDW were $0.23 \%$ (Table 3).

Low phytotoxicity levels were verified in the $C$. ensiformes (Table 3). At $30 \mathrm{DAE}$, the plants grown in the SCLTS demonstrated, at the highest dose, an average phytotoxicity of $10 \%$; while in other tests, the injury levels were insignificant, from 0.20 to $1.0 \%$. This trend reflected in the response of the other variables, such as the plants height, which had linear decreases of $0.07 \%$ for each $g$ ha $^{-1}$ of applied herbicide in both periods and regardless of the soil type that the $C$ ensiformes plants were grown in (Table 3). The SDW production was explained by a decreasing linear model that represented both soil types and had little variation depending on the doses, with a unit reduction of $0.08 \%$. The RDW was not influenced by the herbicide doses, while in SCLTS there was a linear reduction of $0.13 \%$ for each $\mathrm{g} \mathrm{ha}^{-1}$ of applied herbicide (Table 3 ).
When taking the cultivation in SCLTS into account, by promoting significant imazapic effects in the evaluated species, the highest dry matter yields are found in plants of $M$. pruriens, $U$. ruziziensis, $U$. brizantha and $C$. ensiformis when grown as a control group (Table 4). Among these species, $U$. ruziziensis demonstrated greater damage with the increasing doses. Comparatively, it was observed in M. pruriens, $C$. ensiformes and $U$. brizantha the least phytotoxicity effects, which influenced the greater accumulation of dry matter in the shoot and root, criteria used in this study to identify the most tolerant species to imazapic.

The species $C$. ensiformis, $M$. pruriens and $U$. brizantha demonstrated greater tolerance to the increasing imazapic doses. This tolerance attributed to them may be related to their ability in metabolizing or stimulating the soil microbiota through releasing root exudates (Spohn et al., 2013). Once absorbed, the herbicide may have degraded after metabolic or enzymatic transformations, or then compartmentalized in tissues.

Tolerant plants rapidly absorb the imazapic. Newsom et al. (1993) observed that more than $70 \%$ of the applied imazapic to tolerant species was absorbed in the first four hours after the treatment. However, there are no specific reports on the metabolism of this herbicide. In general, the imidazolinones metabolism is mediated by cytochrome P450 monooxygenases per oxidation and hydroxylation of the pyridine ring, resulting in increased polarity of the molecule and its reduced phytotoxicity, followed by its conjugation with carbohydrates (Zhao et al., 2017). When studying the imazamox metabolism in wheat, Rojano-Delgado et al. (2015) observed that the sensitive cultivar was unable to metabolize the herbicide, translocating it from the leaves to the root. In the tolerant cultivar, the metabolism quickly occurred at the highest tested dose $\left(200 \mathrm{~g} \mathrm{ha}^{-1}\right)$ and the metabolites were translocated to the root system.

Leguminous plants such as $C$. ensiformis and Mucuna spp. have demonstrated characteristics of tolerance and adaptation to different abiotic stress conditions, with the potential of immobilizing and accumulating heavy metals (Nam et al., 2016; Boechat et al., 2017) and degrading organic compounds (Madalão et al. 2017). The U. brizantha species is cited as an interesting remediator for herbicides due to its high

Table 4. Dry weight (grams per plant) of species grown as control groups of the imazapic herbicide activity in soils with sandy clay loam texture (SCLTS) and sandy clay texture (SCTS).

\begin{tabular}{lcc}
\hline \multicolumn{1}{c}{ Species } & SCLTS & SCTS \\
\hline Capim-braquiária - Urochloa decumbens & 18.51 & 28.01 \\
Capim-marandu - Urochloa brizantha & 23.46 & 21.44 \\
Capim-ruziziensis - Urochloa ruziziensis & 26.28 & 39.11 \\
Mucuna-cinza - Mucuna pruriens & 33.51 & 18.35 \\
Capim-mombaça - Panicum maximum & 19.85 & 23.11 \\
Sorgo - Sorghum bicolor & 21.75 & 39.58 \\
Crotalaria - Crotalaria ochroleuca & 8.86 & 17.35 \\
Crotalaria - Crotalaria spectabilis & 7.47 & 13.48 \\
Feijão-de-porco - Canavalia ensiformis & 23.42 & 33.49 \\
\hline
\end{tabular}


root density and for acting as a hydraulic barrier by promoting an upward water flow, reducing the molecule leaching (Braga et al., 2016).

Species that attained the best results in terms of tolerance to the treatment with imazapic had high biomass production when grown as a control group (Table 4). Florido et al. (2014) verified a high potential for imazaquin accumulation in Mucuna cinerea leaves, while the Canavalia ensiformis accumulated the highest concentration in its root. There was also a positive correlation between the increased absorption of this herbicide and the higher dry matter production in $C$. ensiformis. According to Madalão et al. (2012), the selection of species tolerant to the herbicide to be removed and that produce a large biomass amount are requirements for the phytoremediation efficiency (Madalão et al., 2012).

Microbial activity is the main degradation agent of the organic compounds. The reduction of toxic effects in tolerant species can also be attributed to the greater phytostimulation potential of the microbiata associated with its roots. Galon et al. (2014) attribute the tolerance found in the species Lolium multiflorum and Vicia sativa treated with the imazapyr-imazapic mixture to the phytostimulation and rhizodegradation of these same plants. As a limiting factor, Souto et al. (2013) report that successive imidazolinones applications may affect the microbial degradation and increase the molecule persistence in the soil, with damage to the succeeding crop. However, Liu et al. (2016) observed that the imazamox increase promoted the enrichment of strains highly adaptable to using herbicide as a carbon source.

With effects less intense than those observed in the other species, the reduction in dry matter and height in C. ensiformis, $M$. pruriens and $U$. brizantha was caused in the highest doses, when grown in SCLTS. Jiménez et al. (2015) found similar results in wheat cultivars treated with the imazamox herbicide. In that same study, chlorophyll tolerance and recovery was attributed to the herbicide metabolism, protein restoration in the chloroplast, herbicide exclusion from the chloroplast, in addition to a possible amino acid substitution at the site of action.

Results presented in this study demonstrate distinct responses from the evaluated species when exposed to imazapic doses. The tolerance of grasses and dicots to the tested doses is due to the differential metabolism of ALS-inhibiting herbicides that are catalyzed by enzymatic systems such as the cytochrome P450 monooxygenases and glutathione S-transferases and by the glucosyl transferases in a lesser extent (Nandula et al., 2019). The plant growth interruption is one of the characteristics that shows sensitivity to the imidazolinones herbicides. Reduction in height, decrease in dry matter production and mortality in less-tolerant species with the increased dose of formulated imidazolinones mixtures have all been reported previously (Galon et al., 2014).

The most affected species by imazapic demonstrated the initial intoxication symptoms, such as leaf chlorosis and necrosis at the low doses. García-Carijo et al. (2012) verified a reduction in the ALS enzyme activity when treatment with imazamox, indicating that the herbicide is mainly transported to growing areas where it acts. These negative effects are described as typical symptoms of plants treated with imidazolinone herbicides, with the first effects observed in meristematic tissues in which high biosynthesis of valine, leucine and isoleucine takes place (Zhou et al. 2007).

In this study, the effect from the imazapic doses on the treated plants was directly influenced by the organic carbon content of the substrate, considering that this experiment was conducted at the same $\mathrm{pH}$ levels (5.25). The imidazolinones activity in the soil is determined by its physical-chemical characteristics, which together with the soil characteristics, will determine the availability and sorption capacity of the molecules. The high organic carbon content $\left(26.8 \mathrm{~g} \mathrm{dm}^{-3}\right)$ verified in SCTS resulted in the bioavailability reduction of the herbicide for phytoextraction. The greater imazapic availability in the soil solution correlates with the highest contents of sand and the lowest of organic matter and clay (Oliveira et al., 2017). The soil characteristics, the molecule behavior, the remediation time and the mechanisms involved in the plant tolerance are all factors that must be taken into account during the selection process of promising phytoremediation species.

\section{Conclusions}

The species Canavalia ensiformes, Mucuna pruriens and Urochloa brizantha all displayed tolerance to imazapic.

Additional experimental analysis, such as the residual quantification through analytical methods are necessary tools for confirming the imzapic removal by these species.

\section{Acknowledgements}

To the Goiano Federal Institute, Rio Verde Campus and the Goiás Research Foundation (FAPEG), for the financial grant.

\section{Literature Cited}

Boechat, C.L.; Giovanella, P.; Amorim, M.B.; de Sá, E.L.S.; de Oliveira Camargo, F.A. Metal-resistant rhizobacteria isolates improve Mucuna deeringiana phytoextraction capacity in multi-metal contaminated soils from a gold mining area. Environmental Science and Pollution Research, v.24, n.3, p.3063-3073, 2017. https://doi.org/10.1007/s11356-016-8103-1.

Braga, R.R.; dos Santos, J.B.; Zanuncio, J.C.; Bibiano, C.S.; Ferreira, E.A.; Oliveira, M.C.; Silva, D.V.; Serrão, J.E. Effect of growing Brachiria brizantha on phytoremediation of picloram under different $\mathrm{pH}$ environments. Ecological Engineering, v.94, p.102106, 2016. https://doi.org/10.1016/j.ecoleng.2016.05.050.

Dor, E.; Smirnov, E.; Galili, S.; Guy, A.; Hershenhorn, J. Characterization of the novel tomato mutant HRT, resistant to acetolactate synthase-inhibiting herbicides. Weed Science, v.64, n.2, p.348360, 2016. https://doi.org/10.1614/WS-D-15-00207.1. 
Duke, S.O.; Stidham, M.A.; Dayan, F.E. A novel genomic approach to herbicide and herbicide mode of action discovery. Pest Management Science, v.75, n.2, p.314-317, 2019. https://doi. org/10.1002/ps.5228.

Empresa Brasileira de Pesquisa Agropecuária - Embrapa. Centro Nacional de Pesquisa de Solos. Manual de métodos de análise de solo. 2.ed. Rio de Janeiro: Embrapa; CNPS, 1997. 212p.

Escoto, D.F.; Gayer, M.C.; Bianchini, M.C.; Cruz Pereira, G.; Roehrs, R.; Denardin, E.L. Use of Pistia stratiotes for phytoremediation of water resources contaminated by clomazone. Chemosphere. v.227, p.299-304, 2019. https://doi.org/10.1016/j. chemosphere.2019.04.013.

Florido, F.G.; Monquero, P.A.; Dias, A.C.R.; Tornisielo, V.L. The absorption and translocation of imazaquin in green manures. Acta Scientiarum. Agronomy, v.36, n.3, p.291-300, 2014. https:// doi.org/10.4025/actasciagron.v36i3.17035.

Galon, L.; Lima, A.M.; Guimarães, S.; Belarmino, J.G.; Burg, G.M.; Concenço, G.; Bastiani, M.O.I; Beutler, A.N.; Zandona, R.R.; Radünz, A.L. Potential of plant species for bioremediation of soils applied with imidazolinone herbicides. Planta Daninha, v.32, n.4, p.719726, 2014. https://doi.org/10.1590/S0100-83582014000400006.

García-Garijo, A.; Palma, F.; Iribarne, C.; Lluch, C.; Tejera, N.A. Alterations induced by imazamox on acetohydroxyacid synthase activity of common bean (Phaseolus vulgaris) depend on leaf position. Pesticide Biochemistry and Physiology, v.104, n.1, p.7276, 2012. https://doi.org/10.1016/j.pestbp.2012.07.004.

Gerhardt, K.E.; Gerwing, P. D.; Greenberg, B.M. Opinion: Taking phytoremediation from proven technology to accepted practice. Plant Science, v.256, p.170-185, 2017. https://doi.org/10.1016/j. plantsci.2016.11.016.

Gerónimo, E.; Aparicio, V.C.; Bárbaro, S.; Portocarrero, R.; Jaime, S.; Costa, J.L. Presence of pesticides in surface water from four sub-basins in Argentina. Chemosphere, v.107, p.423-431, 2014. https://doi.org/10.1016/j.chemosphere.2014.01.039.

Jiménez, F.; Fernández, P.; Rojano-Delgado, A.M.; Alcántara, R.; de Prado, R. Resistance to imazamox in Clearfield soft wheat (Triticum aestivum L.). Crop Protection, v.78, p.15-19, 2015. https://doi.org/10.1016/j.cropro.2015.08.004.

Kemmerich, M.; Bernardi, G.; Adaime, M.B.; Zanella, R.; Prestes, O.D. A simple and efficient method for imidazolinone herbicides determination in soil by ultra-high-performance liquid chromatography-tandem mass spectrometry. Journal of Chromatography A, v.1412, p.82-89, 2015. https://doi. org/10.1016/j.chroma.2015.08.005.

Liu, C.G.; Xin, Y.; Yang, L.; Lu, H.G.; Zeng, W.M.; Gui, G.; Yang, F.S. Imazamox microbial degradation by common clinical bacteria: Acinetobacter baumannii IB5 isolated from black soil in China shows high potency. Journal of Integrative Agriculture, v.15, n.8, p.1798-1807, 2016. https://doi.org/10.1016/S20953119(16)61344-8.

Madalão, J.C.; Pires, F.R.; Cargnelutti Filho, A.; Nascimento, A.F.; Chagas, K.; Procópio, S.O.; Araújo, R.S.; Bonomo, R.; Taufner, G.A. Selection of species tolerant to the herbicide sulfentrazone with potential for phytoremediation of contaminated soils. Semina: Ciências Agrárias, v.33, n.6, p.2199-2213, 2012. https://doi. org/10.5433/1679-0359.2012v33n6p2199.
Madalão, J.C.; Souza, M.F.D.; Silva, A.A.; Silva, D.V.; Jakelaitis, A.; Pereira, G.A.M. Action of Canavalia ensiformis in remediation of contaminated soil with sulfentrazone. Bragantia, v.76, n.2, p.292-299, 2017. https://doi.org/10.1590/1678-4499.526.

Mazlan, A.Z.; Hussain, H.; Zawawi, M.A.M. Potential dermal exposure assessment of farmers to herbicide imazapic in an agriculture area. Procedia-Social and Behavioral Sciences, v.234, p.144153, 2016. https://doi.org/10.1016/j.sbspro.2016.10.229.

Montpetit E.; Lachapelle E. New environmental technology uptake and bias toward the status quo: The case of phytoremediation. Environmental Technology \& Innovation, v.7, p.102-109, 2017. https://doi.org/10.1016/j.eti.2016.12.008.

Nam, I.H.; Roh, S.B.; Park, M.J.; Chon, C.M.; Kim, J.G.; Jeong, S.W.; Song, H.; Yoon, M.H. Immobilization of heavy metal contaminated mine wastes using Canavalia ensiformis extract. Catena, v.136, p.53-58, 2016. https://doi.org/10.1016/j. catena.2015.07.019.

Nandula, V.K.; Riechers, D.E.; Ferhatoglu, Y.; Barrett, M.; Duke, S.O.; Dayan, F.E.; Brazier-Hicks, M. Herbicide metabolism: Crop selectivity, bioactivation, weed resistance, and regulation. Weed Science, v.67, n.2, p.149-175, 2019. https://doi.org/10.1017/ wsc.2018.88.

Newsom, L.J.; Shaw, D.R.; Hubbard, T.F. Absorption, translocation, and metabolism of AC 263,222 in peanut (Arachis hypogaea), soybean (Glycine max), and selected weeds. Weed Science, v.41, n.4, p.523-527, 1993. https://doi.org/10.1017/ S0043174500076256.

Oliveira, L.H.S; Branco, E.P.; Lino, J.S. Fitorremediação de solos contaminados com herbicidas imazetapir e imazapique. Revista Brasileira de Iniciação Científica, v.4, n.4, p.78-111, 2017. https://periodicos.itp.ifsp.edu.br/index.php/IC/article/ viewFile/652/702. 05 Nov. 2019.

Rojano-Delgado, A.M.; Priego-Capote, F.; de Castro, M.D.L.; De Prado, R. Mechanism of imazamox resistance of the Clearfield ${ }^{\circledR}$ wheat cultivar for better weed control. Agronomy for Sustainable Development, v.35, n.2, p.639-648, 2015. https:// doi.org/10.1007/s13593-014-0232-7.

Santos, E.; Pires, F.R.; Ferreira, A.D.; Egreja Filho, F.B.; Madalão, J.C.; Bonomo, R.; Rocha Junior, P.R.D. Phytoremediation and natural attenuation of sulfentrazone: mineralogy influence of three highly weathered soils. International journal of phytoremediation, v.21, n.7, p.652-662, 2019. https://doi.org/1 $0.1080 / 15226514.2018 .1556583$.

Sousa, C.P.; Bacarin, M.A.; Pinto, J.J.O. Growth of residual herbicide (imazethapyr+imazapic) bio-indicators sown in rotation with Clearfield $^{\circledR}$ rice Planta Daninha, v.30, n.1, p.105-111, 2012. https://doi.org/10.1590/S0100-83582012000100012.

Souto, K.M.; Jacques, R.J.S.; de Avila, L.A.; de Oliveira Machado, S.L.; Zanella, R.; Refatti, J.P. Biodegradation of the herbicides imazethapyr and imazapic in rhizosphere soil of six plant species. Ciência Rural, v.43, n.10, p.1790-1797, 2013. https:// doi.org/10.1590/S0103-84782013001000010.

Spohn, M.; Ermak, A.; Kuzyakov, Y. Microbial gross organic phosphorus mineralization can be stimulated by root exudates $-A{ }^{33} \mathrm{P}$ isotopic dilution study. Soil Biology and Biochemistry, v.65, p.254-263, 2013. https://doi.org/10.1016/j. soilbio.2013.05.028. 
Tripathi, V.; Fraceto, L.F.; Abhilash, P.C. Sustainable clean-up technologies for soils contaminated with multiple pollutants: Plant-microbe-pollutant and climate nexus. Ecological Engineering, v.82, p.330-335, 2015. https://doi.org/10.1016/j. ecoleng.2015.05.027.

Velini, E. D.; Osipe, R.; Gazziero, D. L. P. (Coords.). Procedimentos para instalação, avaliação e análise de experimentos com herbicidas. Londrina: SBCPD, 1995. 42p.
Zhao, B.; Fu, D.; Yu, Y.; Huang, C.; Yan, K.; Li, P.; Shafia. J.; Zhua, H.; Weia, $\mathrm{S} . ; \mathrm{Ji}, \mathrm{M}$. Non-target-site resistance to ALS-inhibiting herbicides in a Sagittaria trifolia L. population. Pesticide Biochemistry and Physiology, v.140, p.79-84, 2017. https://doi.org/10.1016/j.pestbp.2017.06.008.

Zhou, Q.; Liu, W.; Zhang, Y.; Liu, K.K. Action mechanisms of acetolactate synthase-inhibiting herbicides. Pesticide Biochemistry and Physiology, v.89, n.2, p.89-96, 2007. https://doi.org/10.1016/j. pestbp.2007.04.004. 